UDC 340.15:[623.4:316.48]](477.8)"2014/2020"(043.2)

DOI https://doi.org/10.32841/ILA.2020.23.20

\author{
MYKHAILIV T. YE., \\ Postgraduate Student \\ Petro Mohyla Black Sea National University
}

\title{
REASONS OF THE WAR CONFLICT IN THE EAST OF UKRAINE AND THE PATH TO RECONCILIATION
}

Summary. The whole world is struggling because of pandemic of Corona virus, and the world economy is slowly moving towards recession. In addition to these new challenges, Ukraine faces many other problems that affect the future of the Ukrainian nation. One of the most important issues remains the military-political conflict in the eastern region, which must end in order to restore Ukrainian statehood and ensure peace for the citizens of Ukraine.

The conflict between Ukraine and Russia began in February 2014 and continues to this day. Russian Federation annexed the Autonomous Republic of Crimea and Sevastopol, occupied certain areas of Donetsk and Luhansk regions violating the rules and principles of international law, bilateral and multilateral agreements.

Russia, by its state ideology and philosophy, is a country that has always been trying to dominate its neighboring countries. The absorption of Ukrainian raw materials, territory and human resources is one of the key prerequisites for the deployment of the Russian imperial project. In order to gain dominance in the region, Russia often starts a hybrid wars on the territories of neighbors. Russia's aggression should be considered in the context of the general geopolitics of the Russian Federation. The "problem of Ukraine" for Kremlin is critically important on a regional scale - to ensure a controlled "zone of self-interest" in the post-Soviet space.

The conflict has led to the loss of basic human values, such as respect for human life, dignity, justice, and so on. This has further exacerbated corruption in society, intolerance and confrontation.

Reconciliation should be started not from the top, but from the bottom, namely between the citizens of Eastern Ukraine and other regions. Ukraine must offer new ways to solve the problem in which the citizens of Eastern Ukraine will be willing to return to Ukraine.

In order to be able to preserve its sovereignty in the occupied territories, Ukraine must already do everything possible in both domestic and international arenas. All Ukrainian society and international partners must be convinced that Eastern Ukraine and Crimea are occupied by Russia, and Ukraine will never give up working to bring these regions back.

Key words: conflict, international law, occupation, international partners, confrontation.

Formulation of the problem. The whole world is struggling, because of the pandemic of corona virus and world economy is slowly sliding into recession. Besides these new problems, Ukraine faces a lot of other different challenges, which influence the future of Ukrainian nation. One of the most important question remains the military-political conflict in its Eastern region, which has to come to the end in order to restore Ukrainian statehood and bring peace to Ukrainian citizens. 
Analysis of recent research and publications. Despite of the numerous articles, books and discussions dedicated to the armed conflict between Ukraine and Russian, there is little attention paid to the historical and religious background that lies in the core of the conflict.

The aim of this article is to investigate the reasons of the conflict.

Presentation of the main research material. The conflict between Ukraine and Russia started in February 2014 and lasts till today. Violating rules and principles of international law, bilateral and multilateral agreements, the Russian Federation annexed the Autonomous Republic of Crimea and Sevastopol, occupied certain areas of Donetsk and Luhansk regions. The war conflict in the Eastern Ukraine started in April 2014 and already took the lives of 13000 people, not considering those who are missing. Nearly 1.5 million residents of Eastern Ukraine have been forced to leave their homes and relocated to other regions of Ukraine. The infrastructure of the occupied regions has been destroyed and $27 \%$ of the Donbas industrial potential has been illegally relocated to Russia. Geographically, the border between Russian Federation and Ukraine is $2295 \mathrm{~km}$. Due to the Russian occupation of the Crimea in 2014 and war conflict in the Eastern Ukraine, Ukraine does not control $409 \mathrm{~km}$ (18\%) of the land border and about $430 \mathrm{~km}$ of the sea border [1, p. 40].

In order to better understand the reasons that caused a war conflict, we should get a closer look at the historical basis, where we can clearly state that the Russian-Ukrainian confrontation has deep historical roots. Ukraine is much older than Russian. The formation of Ukraine dates back to the $5^{\text {th }}$ century during the reign of Kievan Rus. The first mention of Ukraine as a separate independent state dates back to 1187. At that time Kievan Rus was a huge (1 $\left.300000 \mathrm{~km}^{2}\right)$ and powerful state. It inhabited around $7.9 \mathrm{mln}$ people and was considered as one of the most powerful economies of that time, competing with Byzantine Empire. In contrast, Novgorod region (Russia), was just an eastern part of Kievan Rus. During the Mongol invasion in 1240, Kievan Rus was completely demolished, except its Novgorod region (Russia), which was untapped by Mongol and started to prosper and exercise its imperial ambitions on its former family. Contrary to Kievan Rus, Novgorod region did not fight, but joined the Mongol and used the invasion in order to gain preference in the region.

The origins of the modern Russian-Ukrainian war can be found in the period of the formation of the Russian Empire and its confrontation with the Ukrainian state. The Konotop battle of 1659 became the starting point of the armed conflict, where the Ukrainian troops of Hetman Vyhovsky defeated the Moscow army. An important stage of the confrontation was the battle of Poltava in 1709, in which Tsar Peter I secured the consolidation of Russian influence on the territory of the Hetmanate and accelerated the processes of creation of the Russian Empire. Then, Ukraine has its independence during separate periods and gained its full independence from Russian in 1991, after the collapse of the USSR.

Even today, the imperial mentality of Russian Federation cannot imagine itself without Ukraine. Russia, by its state ideology and philosophy, is a country 
that has always been trying to dominate its neighboring countries. The absorption of Ukrainian raw materials, territory and human resources is one of the key prerequisites for the deployment of the Russian imperial project. In order to gain dominance in the region, Russia often starts a hybrid wars on the territories of neighbors.

The concept of hybrid war was also developed by Russian scientists and military personnel. During the meetings at the Academy of Military Sciences in 2013, head of the Joint Chiefs of Staff of Russia Federation General Valeriy Gerasimov described modern war as following: "The methods of doing war are shifted to political, economic, informational, humanitarian and other innovative activities which are exercised together with riots and protests. All that is complemented by disguised military actions, informational war and use of Special Forces. The war is done openly only under the appearance of peacemaking and crisis response and only in the final stages in order to reach a success in the conflict" $[4$, p. 170].

It is worth to mention that Ukraine is a multinational country. For many centuries, millions of Russians lived on the territory of Ukraine, mainly on its eastern regions. The table below shows the correlation between different ethnic groups in Ukraine in 2019.

Table 1

\begin{tabular}{|c|c|c|}
\hline Rank & Ethnic Group & Share of National Population of Ukraine \\
\hline 1 & Ukrainian & $77.5 \%$ \\
\hline 2 & Russian & $17.2 \%$ \\
\hline 3 & Romanian & $0.8 \%$ \\
\hline 4 & Belorussian & $0.6 \%$ \\
\hline 5 & Crimean Tatar & $0.5 \%$ \\
\hline 6 & Bulgarian & $0.4 \%$ \\
\hline 7 & Hungarian & $0.3 \%$ \\
\hline 8 & Polish & $0.3 \%$ \\
\hline 9 & Jewish & $0.2 \%$ \\
\hline 10 & Armenian & $0.2 \%$ \\
\hline
\end{tabular}

The Russian Empire and then USSR, did their best to destroy the local Ukrainian population. It is officially recognized that during $20^{\text {th }}$ century, there were three famines on Ukrainian territory (Famines of 1921-23, 1932-33, 194647), which are recognized as genocide of a Ukrainian nation. Only famine of 1932-33 took lives of about 4 million Ukrainians, which put the future of Ukrainian nation in jeopardy, as per se. Right after famines, the territories was intentionally densely populated by people of Russian nationality, which led to a change in the gene pool of the eastern and southern parts of Ukraine. Those people were granted a lot of preferences (tax relieves, free households, criminal records were erased etc), which put a local population into a disadvantages position.

Despite of numerous actions taken throughout of centuries against the existence of Ukrainian nations, Ukrainians finally gained its independence. 
The adoption of the Declaration of Independence of Ukraine by Parliament of Ukrainian Soviet Socialist Republic on 24 August 1991 shows the strong will and desire of Ukrainian finally have its own independent state.

The general Referendum was held on December 1, 1991, at which citizens of the country voted for the independence of Ukraine. One question was put to the referendum: "Do you confirm the Declaration of Independence of Ukraine?" The text of the Act, (approved by the Parliament on August 24, 1991), was included in the ballot. Citizens of Ukraine voted in favor of independence. $84,18 \%$ (31 891742 citizens) of the population of Ukraine took part in the referendum and 90.32\% (28 804071 people) of them voted in favor.

Below you can find a map which indicates the percentage of citizens who voted against the Independence. Crimea, due to a majority of Crimean tatars, wanted to get its own Tatarian state. Therefore, $42 \%$ of citizens voted against the independence of Ukraine. However, Crimea joined Ukraine as an autonomous region (Fig. 1) [5, p. 181].

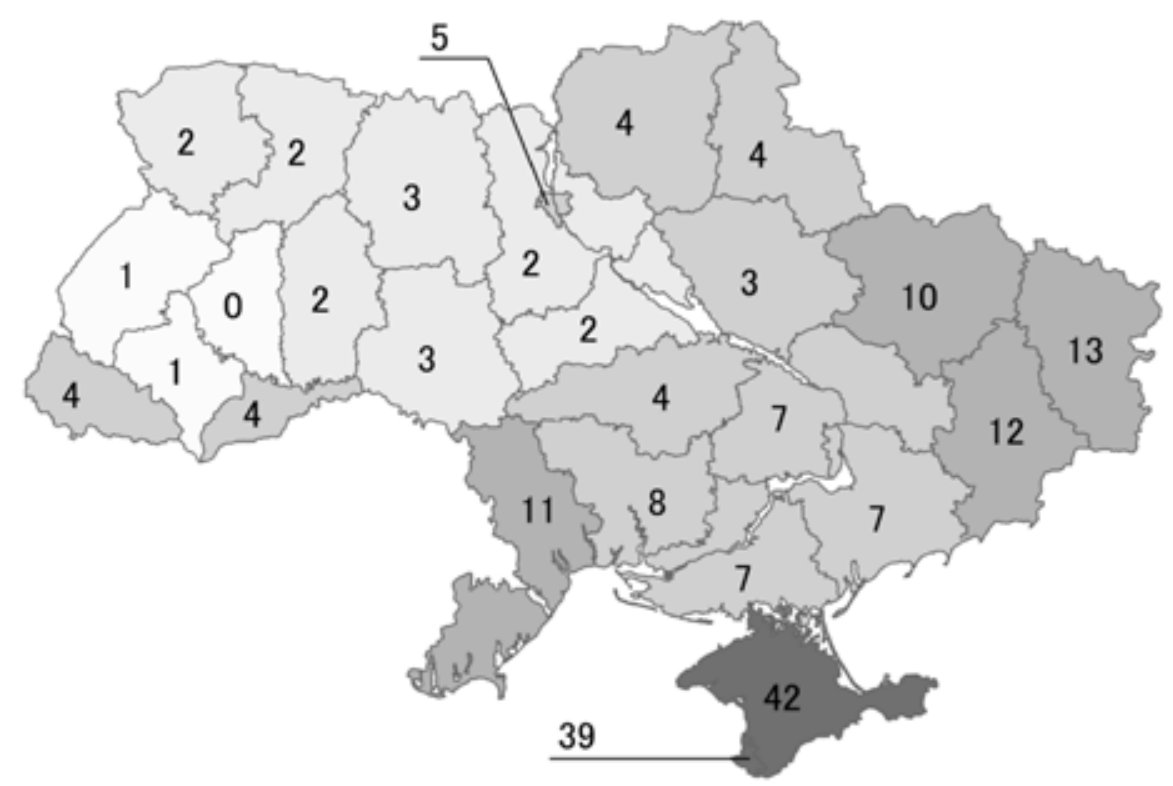

\begin{tabular}{|l|l|l|l|l|}
\hline $100-30 \%$ & $30-10 \%$ & $9-4 \%$ & $3-2 \%$ & $1-0 \%$ \\
\hline
\end{tabular}

Fig. 1

The regions of Ukraine with the highest non-Ukrainian population had, respectively, a lower support for Ukraine's independence. These were the first signals of those events that subsequently lead to the annexation of Crimea and war.

The next stage of the escalation happened in November, 2004, when Ukraine was in the middle of President Elections which divided the country. The results were announced On November 24, 2004, where two candidates were competing against each other: Viktor Yanukovych, who had a strong support in the southern 
and eastern regions of Ukraine, and Viktor Yushchenko, who had the support of the central, northern and especially western regions.

In the first round, Viktor Yanukovych got $39.26 \%$ of votes, being on the $2^{\text {nd }}$ place among 24 contenders and Viktor Yushchenko got 39,90\% of votes, staying on the $1^{\text {st }}$ place.

In the second round, according to an official statement by the Central Election Commission, Viktor Yanukovych won the election ( $49.46 \%$ of the vote).

However, since the election results in the areas (eastern and southern regions), where Viktor Yanukovych had the strong support of the voters, were highly corrupted and its results were questionable, the Supreme Court acknowledged that it was impossible to establish reliable voting results. [2, p. 148].

The aforementioned events have led to a political crisis in Ukraine with a widespread peaceful demonstration known as the Orange Revolution. The Supreme Court of Ukraine annulled the official results and ordered the second round of voting to be repeated. Thus, the second round was re-voted and Viktor Yushchenko became the President of Ukraine (Fig. 2).

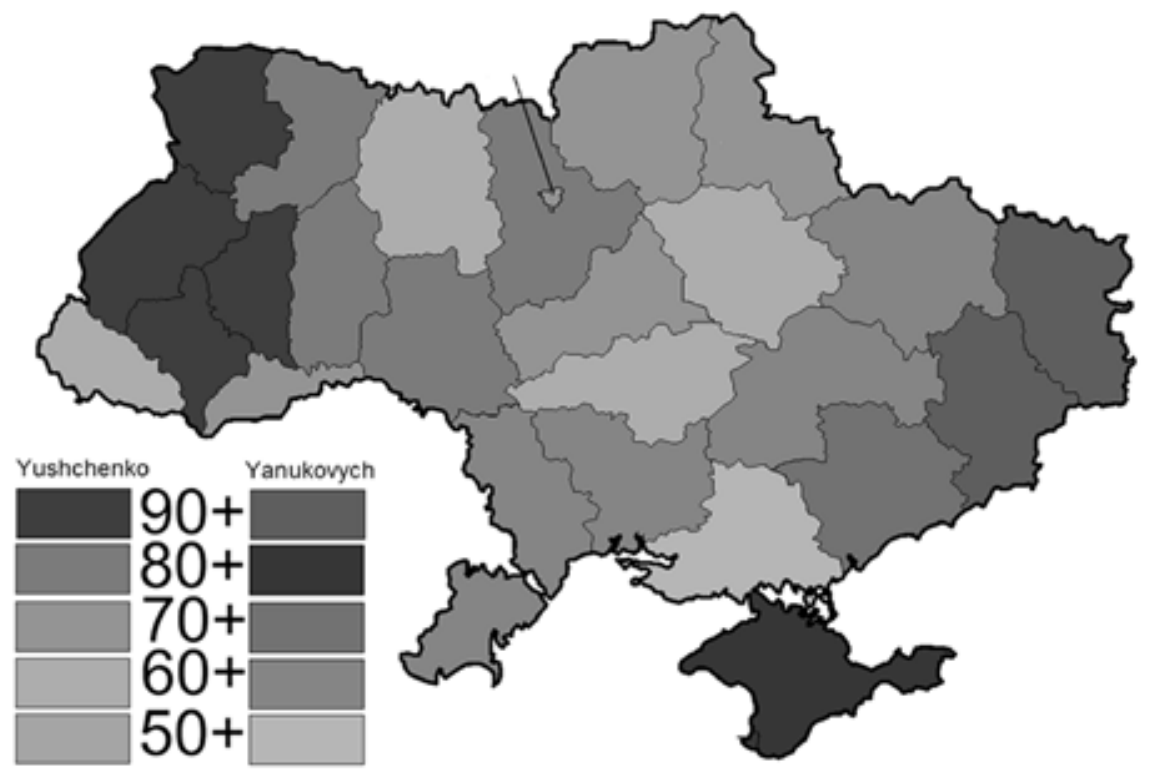

Fig. 2

It is important to mention, that Russian Federation has always influenced the northern and eastern parts of Ukraine and clearly supported (financially and with the help of media) the pro-Russian candidate Viktor Yanukovych who eventually lose the Presidential run and escaped to Russia when the war with Russia began.

Meanwhile, the first ideas of independent Crimea were announced in Congress of Deputies of the Parliament of the Autonomous Republic of Crimea on November 26, 2004. However, the majority of deputies suppressed such ideas, as non-relevant and dangerous. 
All these events, especially manipulation of information, led to the formation of two opposite opinions between Ukrainians in the East and West.

Another important domain to consider is the religious factor and its influence on the events in Ukraine and the Church's ability to resolve the conflict in the Eastern Ukraine.

The major religion in Ukraine is Christianity and it is divided between three major streams:

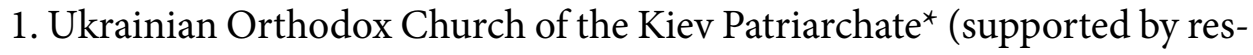
idents of Central Ukraine). The center is based in Kiev.

2. Russian Orthodox Church (Eastern Ukraine).* The center is based in Moscow.

3. Catholic Church (Eastern and Western Rites) is wide spread in Western Ukraine. The center is in Vatican.

* Ukrainian and Russian Orthodox Churches are in religious, organizational and political opposition to each other.

The fate of Ukrainian Churches and Catholic churches was very tragic during Soviet rule, because parishioners were subjected to particular persecution. Soviet society tried to build an atheist country where it challenged God and the values of the Christian world. In general, the transition to the idea of building an "atheistic" state came to an end in the late 1920s and weakened in the 1970s.

The Catholic Church was particularly persecuted during the Soviet period (1918-1991) as it objected to the confiscation of church property and had its leadership outside the Soviet Union. By mid-1937, the activities of the Catholic Church in the USSR were virtually paralyzed. At the beginning of 1939, only two Catholic churches functioned in the Soviet Union (in Moscow and in Leningrad), and only because two priests of foreign citizenship took care of them. The materials published in the Book of Remembrance give reason to speak of the persecution of a 601 Catholic priest: 187 killed; the fate of 168 priests remained unknown; 92 priests, after serving their sentences, remained alive and another 154 were able to go abroad after being released. Western Ukraine joined the Ukrainian SSR in 1939, which is why a new round of repression against the Catholic Church has taken place on these lands since 1939. According to archival data, about 200,000 were killed in Western Ukraine (Memorial to martyrs of the twentieth century).

Orthodox Church (name as Russian Orthodox Church) was persecuted in a lesser manner due to the fact that the it had almost a thousand years of history and tradition in the Ukrainian lands (the baptism of Ukraine (Kievan Rus) took place in Kyiv in 988. A part of the Orthodox Church adapted to the times and conditions established by soviet authorities and cooperated with the government, which enabled it to continue functioning within the country.

Declaration of Independence of Ukraine provided an opportunity to restore the existence of the Ukrainian Orthodox Church of the Kyiv Patriarchate and the Catholic Church of Western and Eastern Rites. These churches have been actively involved in helping to resolve the conflict in Eastern Ukraine. 
We believe that the destruction of the religious foundation of Ukrainian society during the Soviet Union has led to the loss of basic human values such as respect of human life, dignity, justice etc. This further led to increased corruption in society, intolerance and confrontation, which manifested itself in the war in eastern Ukraine.

The main factor that boosted the events, which led to the annexation of Crimea and war in Eastern Ukraine was the Revolution of Dignity. The incompatibility of the state's domestic policy with the interests of Ukrainians resulted in an open confrontation with the authorities after its refusal to integrate the country with European Union.

The confrontation started as a peaceful protests of Ukrainians, which were brutally suppressed by the authorities, which led to deaths of peaceful protesters and escalating of the protests into the armed conflict.

The Ukrainian people explicitly exercised their natural right to rebel against a political regime that usurped power, used it solely for its own enrichment, repressing all its opponents, grossly violating human rights and fundamental freedoms. Ukrainians have shown that for many of them freedom, justice, honor and dignity are more important than their own lives. These events have been named in Ukraine and the world as the "Revolution of Dignity".

In the Eastern Ukraine, manifestations of the pro-Ukrainian opinion have led to political persecution, as a result of which many Ukrainian activists and journalists of the East have been forced to relocate to other regions of Ukraine, and those who stayed became the target of political persecution [3, p. 340].

As of March 30,2017, more than 1.59 million people were officially relocated due to the war in eastern Ukraine and Russia's occupation of the Crimean peninsula. Most of the relocated citizens are from the occupied territory of Donetsk region (more than 532 thousand) and Luhansk region (almost 291 thousand) (Migration from Occupied Territories).

Russia's aggression against Ukraine and in particular the annexation of Crimea and intervention to the East, should be considered in the context of the general geopolitics of the Russian Federation. The "problem of Ukraine" for Kremlin is critically important on a regional scale - to ensure a controlled, managed "zone of self-interest" in the post-Soviet space.

Another factors that influenced the emergence of the conflict are cultural and educational.

Residents of Eastern Ukraine do not perceive Ukraine's European integration intentions in contrary to citizens of Central and Western Ukraine, who have significant background in international, cultural, professional and educational international programs.

Consequently, we believe that the historical background and mentality are the important factors that gradually led to a conflict with the support of the Russian state.

It is necessary to start reconciliation not from the top but from the bottom, namely, between the citizens of the Eastern Ukraine and other regions. To do 
this, Ukraine must offer such solutions to the problem in which the citizens of Eastern Ukraine will have a desire to return to back to Ukraine.

According to State Statistics Service of Ukraine during 2011-2014 citizens of Ukraine, most often traveled to the republics of the former USSR - Russia, Belarus and Moldova. However, the number of trips have been steadily declining: in $2011-47.2 \%$, in $2012-46 \%$, in $2013-43.4 \%$, in $2014-38.7 \%$ and in $2015-40.8 \%$.

The second largest number of trips of Ukrainian citizens abroad in 20112015 was to European Union. The number of visits by citizens of Ukraine to Australia, Asia and Africa in 2011-2015 did not collectively exceed the ten percent barrier. At the same time, the countries of North and South America during this period had an extremely small number of visits by Ukrainian citizens.

Since a lot of Ukrainians travelled to European Union, they were able to experience the level of life and culture they wanted to have in Ukraine. Thus, it became obvious to make a choice in favor of integration with European Union rather than with Russian.

We assume that cultural exchange promotes the acquisition of the best traditions from other cultures, respect between people, tolerance and the desire for change and transformation.

We see the following path to reconciliation:

1) to achieve a compromise of the regulation of the status of occupied regions by involving the leaders of Germany, France, the USA and Russia.

2) the use of resources of religious communities through the idea of mediating the reconciliation process in the eastern regions. It is worth noting that for several years the inter-confessional organization Christian Salvation Service has been conducting its social service in the east of Ukraine to assist people in the frontline areas. The "Pope for Ukraine" campaign, which constantly calls for reconciliation in Ukraine, deserves special attention. Over the two years, the program has reached about 900,000 war-affected individuals, regardless of affiliation with religious denominations, both in the occupied territory and in the controlled territory of Ukraine, which increases the level of trust in the Catholic Church. (given that the two other Orthodox churches are in conflict with each other and have different adherents).

3) propose an economic program for the development of the region, which will enable the inhabitants of the region to approach the issue of conflict resolution and reconciliation from the prospect of their economic hope for the future.

We agree with the experts' opinion on the development of Ukraine's foreign policy which should consider the Russian direction, as one of the most risky for state sovereignty. In preparation of the mentioned Strategy, it is advisable to develop and publish a White Paper "Donbas Reintegration: Objectives, Methods, Government Policies", which should in particular mention:

- the world experience of returning and reintegration of occupied territories which should be analyzed in the Ukrainian context. 
- outlined principles on which the reintegration of territories will be carried out;

- outlined tasks and main directions of reconstruction and socio-economic development.

We are convinced that it is necessary to gradually form a comprehensive, coordinated nationwide system of confronting hostile information influence by the Russian Federation in the following areas:

- effective counteraction to mass information expansion can be achieved primarily through the production and distribution of its own competitive media product;

- regularly and openly discuss on the state level the strategy of conflict reconciliation.

As a conclusion, we would like to emphasize that in order to have an opportunity to save and retain the sovereignty on the occupied territories, Ukraine already has to do its best both on the domestic and international arenas. The whole Ukrainian society and international partners should be convinced that Eastern Ukraine and Crimea are occupied by Russia and Ukraine will never give up working on returning those regions back.

\section{References:}

1. Armed conflict in Ukraine: military support for the illegal Armed Forces of the DNR and LNR by the Russian Federation / O. Harbar, A. Konopkin, O. Korenkov, S. Movchan, Edited by: O. Pavlichenko, O. Martynenko / Ukrainian Helsinki Union of human rights. K., 2018. 40 p.

2. Gnatiuk L.P. (2005) The Presidential Election and the Orange Revolution: Impact on Transformation Processes in Ukraine / them. Friedrich Ebert; Edited G. Kurt et al. K. : Testament, 2005. 148 p.

3. Martynenko O.A. (2015) Human rights in Ukraine - 2014. Report of human rights organizations / Edited by: O.A. Martynenko, E.Y. Zakharova / Ukrainian Helsinki Human Rights Union. Kharkov : Publishing House of Human Rights, 2015. 340 p.

4. Lutken G.V. A Slight Invasion in the Interpretation of War in the West. Vetnik Vennogo Universiteta. 2010. No. 2 (22). P. 170-174.

5. Androshchuk O.V. (2012) Referendum on December 1, 1991. Encyclopedia of History of Ukraine: in 10 volumes / ed.: VA Smoly (chairman) and others. ; Institute of History of Ukraine NAS of Ukraine. K.: Sciences. Thought, 2012. Vol. 9: Prix-S. P. 181.944 p. : il. ISBN 978-966-00-1290-5.

\section{Михайлів Т. Є. Причини збройного конфлікту на сході України та шлях до примирення}

Анотація. Увесь світ бореться 3 пандемією коронавірусу, а світова економіка повільно рухається на зустріч рецесії. Окрім цих нових проблем, Україна стикається 3 багатьма іншими викликами, які впливають на майбутнє української нації. Одним із найважливіших питань залишається військово-політичний конфлікт у східному регіоні, який повинен завершитися, щоб можна було відновити українську державність і забезпечити мир громадянам України. 
Конфлікт між Україною та Росією розпочався в лютому 2014 року і триває до сьогодні. Порушуючи правила та принципи міжнародного права, двосторонніх і багатосторонніх угод, Російська Федерація анексувала Автономну Республіку Крим і Севастополь, окупувала окремі райони Донецької та Луганської областей.

Росія за своєю державною ідеологією та філософією $є$ країною, яка завжди намагалася домінувати над сусідніми країнами. Використання української сировини, захоплення української території та використання людських ресурсів $€$ однією з ключових передумов розгортання російського імперського проєкту. Для того, щоб отримати домінування в регіоні, Росія часто починає гібридні війни на територіях сусідів. Агресію Росії варто розглядати в контексті загальної геополітики Російської Федерації. «Проблема України» для Кремля надзвичайно важлива в регіональному масштабі для забезпечення контрольованої «зони власних інтересів» на пострадянському просторі.

Історичне минуле та менталітет є важливими факторами, які поступово призвели до конфлікту через підтримку Російської держави. Конфлікт призвів до втрати основних людських цінностей, таких як повага до людського життя, гідність, справедливість тощо. Це ще більше призвело до посилення корупції в суспільстві, нетерпимості та конфронтації.

Починати примирення потрібно не згори, а знизу, а саме між громадянами Східної України та інших регіонів. Для цього Україна повинна запропонувати такі шляхи розв'язання проблеми, за яких громадяни Східної України матимуть бажання повернутися назад в Україну

Для того щоб мати можливість зберегти суверенітет на окупованих територіях, Україна вже повинна зробити все можливе як на внутрішній, так і на міжнародній аренах. Усе українське суспільство та міжнародні партнери повинні бути впевнені, що Східна Україна та Крим є окуповані Росією і Україна ніколи не відмовиться від роботи з повернення цих регіонів назад.

Ключові слова: конфлікт, міжнародне право, окупація, міжнародні партнери, конфронтація. 